IKONOMIKA: Jurnal Ekonomi dan Bisnis Islam

Volume 5, No 2 (2020)

ISSN : 2527-3434 (PRINT) - ISSN: 2527-5I43 (ONLINE)

Page : 27I - 296

\title{
Modeling Debt And Equity Crowdfunding Based On Murabahah, Musharakah And Mudarabah: Trust And Awareness
}

\author{
Tijjani Muhammad ${ }^{1}$, Assoc. Prof. Dr. Besar bin Ngah²
}

Federal University, Gashua, Yobe State, Nigeria. Department of Islamic Studies (Islamic Banking and Finance) $^{1}$

Al-Madinah International University Malaysia. Department of Islamic Banking and Finance ${ }^{2}$

drbesar.ngah@,mediu.edu.my ${ }^{1}, \underline{\text { hajiteee@,fugashua.edu.ng }}{ }^{2}$

\begin{abstract}
Crowdfunding become one of the most effective alternatives for raising funds, although it is not a new phenomenon in developed and developing countries but seems to be new in Nigeria. As such, the study aims to propose Shariah framework that addresses conventional debt and equity crowdfunding, instead, using Murabaha as debt, Mudarabah and Musharakah as equity model and further measure the level of awareness and trust towards behavioural intention towards crowdfunding in Northern Nigeria. The sample was collected from 2730 purposively selected and used Structural Equation Modeling (SEM) for data analysis. Findings, revealed that the proposed structural framework of crowdfunding proved to enhance entrepreneur vision for raising investment fund based on Shariah-compliant in Northern Nigeria. Further indicates, lack of awareness and inappropriate use of internet platform resulted in perceived entirely irrelevant investment opportunities and developed fair to invest online. Practical implications: The paper provides awareness and trust on how to improve debt and equity-based crowdfunding for a fundraiser and successful funding a business structure based on Shariah compliant. Originality/Value: the study makes significant contribution towards propose Shariah framework of crowdfunding in Nigeria, and it provides awareness and trust to Nigerian Muslims entrepreneurs as in line with Shariah-compliant.
\end{abstract}

JEL Classification: E4, O3I, O35

Received: December 2I,2020 - Revised: December 2I,2020 - Accepted: January 02,202I

Occupuation : Federal University, Gashua, Yobe State, Nigeria ${ }^{1}$, Al-Madinah International

University Malaysia ${ }^{2}$

E-mail : drbesar.ngah@mediu.edu.my ${ }^{1}$, hajiteee@,fugashua.edu.ng ${ }^{2}$ 
Keywords: Crowdfunding, Awareness, debt-based, equity-based, Shariah-compliant

\section{A. INTRODUCTION}

Crowdfunding is considered a significant trend in the global market despite it is not a recent phenomenon for developed and developing countries as predicted. Although it is new phenomenon in Nigeria. The Security Exchange Commission has been threatening to reform and regulate the platform. Since 2012, crowdfunding has been used as a mechanism for fundraising (Rahman, Thaker and Duasa, 2020). Entrepreneurs are widely benefitting from crowdfunding using the most recognized and popularly known platform such as Indiegogo and Kickstarter, which are based in the United States (US). Nigeria has also acknowledged some selected crowdfunding platforms such as MicroVentures, Naijafund, crowdfunder, crowd cube and fund an Enterprise and many more. Therefore, such fundraiser's platforms were not popularly known in Northern Nigeria, due to their operational activities based on conventional system, which advertise both lawful and unlawful activities (Akwe \& Garba, 2019). The investigation shows there is no crowdfunding companies operates based on Shariah framework in the country (Sapovadia, 2017). Moreover, the country witness numbered of equity and debt crowdfunding licensed, no single one was guided by Shariah framework. With such set-back, the conventional crowdfunding keeps increasing day by day (Akwe \& Garba, 2019).

Collectively, SEC has successfully developed crowdfunding new guidelines in the last nine (9) months to cover online campaigns by considering the rampant growing of the sector despite low awareness in the country particularly Northern Nigeria (Ajai, 2020). In contrary, Malaysia, in 2015, had made a history of been the first country established the legality of the equitybased crowdfunding on the basis of Shariah framework and licensed six crowdfunding companies operating locally based on their cultural and traditional transaction (Rahman, Duasa, and Kamil, 2016).

It is essential to understand that awareness and transparency are the keys for acceptance and participating the crowdfunding platforms by the both investors and entrepreneurs. The awareness and transparency may be disclosed by filming a short video with comprehensive information need to be presented to a particular crowdfunding platform. The video gives insight on company background and purpose of fundraising. The video also defines the return or 
reward to be allocated or obtained by the investor, which may be in monetary or otherwise. On the other hand, debt-based and equity-based crowdfunding offer a return in monetary incentives as the rate of return to the investor depends on cost contributed related to the fundraising activities (Freedman Nutting, 2015).

Another type of crowdfunding operates in line with conventional lending and the yield return which is considered as an interest to the investors, and is known as peer-to-peer lending, this type of investment is purely interest-based which Muslims are strongly admonished to avoid and keep aloof from as not in line with Shariah compliant (Torabi \& Mirakhor, 2020). Instead, the Murabahah investment propose to replace conventional debt-based financing for Muslim inclusion and funding businesses. While equity-based is another type of crowdfunding whereby investors received in exchange, a percentage of ownership proposition of the company based on amount contributed as can be classified into Mudarabah and Musharakah. Thus, investments directions can be used as purely Shariah compliant and secure the futures of businesses and fundraising platforms that is attributed to the Shariah means of transaction. Therefore, the entrepreneur must convince the investors on the product to be developed and scheduled its stages of growth for successful take-off. The terms and conditions of the existing company must be visible and readable. However, an entrepreneur must understand that the investors are awaiting for an investment return in the form of dividend after some period stipulated. On this note, the current structural development on crowdfunding would encourage Muslim entrepreneurs to utilize such mechanism and enthusiastically developed the potential cognizance of Shariah framework investments based on debt and equity crowdfunding using Shariah framework which help to regulate and convert the conventional system to take part in line with SEC guideline and enhance the economic growth of the country.

\section{Objectives}

- Propose a Shariah framework that could address conventional debt and equity-based crowdfunding using Murabaha as debt, Musharakah and Mudarabah as equity-based crowdfunding

- Empirically test the relationship between the Awareness and Trust towards behavioural attitude of Muslims on crowdfunding in Northern Nigeria. 


\section{B. THEORITICAL}

Many studies were conducted and investigated the development of crowdfunding from different parts of the globe. Most researchers focused on reviving the Shariah framework connected with the crowdfunding structure, if the Muslims want to participate and avoid any prohibited transactions. Early study found that there was a business challenges in Nigeria, which mainly depends on lack of funding opportunities (Muhammad \& Salisu, 2018). The cost of financing business from the financial institutions is higher, and entrepreneurs are afraid to access such facilities (Wennberg, Pathak, \& Autio, E. (2013). Crowdfunding becomes interested and easier way of generating funds to finance a business in exchange for paying back debt or earn a return. In equity crowdfunding as contributor become part and parcel of the company owner. Equity share amongst the initial equity contributors receives a financial return as dividends from the investment profit distribution. While debt-based crowdfunding allows mediating companies to raise financing in the form of loans, which will be settled back to the lender over a stipulated period agreed upon with the interest rate attached (Davis \& Cartwright, (2019). Reward-based crowdfunding allows the contributor to contribute based on rewards earning or discounted product as finished by the producer or innovator (Kuppuswamy, \& Bayus, 2017). Donation-based crowdfunding motivates donators to donate such a supporter contribute not for financial gain; instead, the contributors are satisfied and happy with the kind of fund utilise through charity institutions (Brulle, 20I4). Thus, each type of crowdfunding stated above has its different type of operational mode. Therefore the study focus on debt and equity crowdfunding to be strengthened through Murabaha as debt and Mudaraba, Musharakah as equity-based crowdfunding.

Since the emergence of crowdfunding, the researchers have discussed much on crowdfunding issues, especially from equity-based, such as (Hornuf \& Schmitt, 20I6; Moritz and Block, 20I4; Brem and Wassong, 20I4). Is also mentioned by some authors on the area of crowdsourcing and crowdfunding such as Hagedorn \& Pinkwart (2016), Stanko \& Henard (2017), and (Lipusch, Dellermann, Bretschneider, Ebel, \& Leimeister, (2020), those researchers mostly focused on crowdfunding and crowdsourcing in the general perspectives as some discussion on the emphasis on the motivational aspect of crowdfunding strategy such as (Hagedorna, \& Pinkwartb, 2013). In a general aspect, Grèzes, Emery, Schegg, \& Perruchoud, (2015) argue that the system of crowdfunding can be considered more efficient in generating fund compared to individuals and its 
importance coverer a pearl of wisdom and ability to demonstrate efficiency in order to have a better solutions and overall method of financing.

Equity crowdfunding conventionally classified risky and element of uncertainty attached, where the entrepreneurs hide information for the investors to a certain stipulated period; as at the early stage, no information available to the investor at the take-off stage of investment, which considered unethical and information asymmetry related. In this context, it is questionable, the entire conventional system and the venture quality and ability to earn legitimate cash flow, which may be against Shariah-compliant (Alam, \& Rajjaque, 2016).

Some researchers have several campaigns-level calling restructure equitybased financing which lead to the gap between the entrepreneurs and investors. Avoidance of Hiding information will significantly minimized a moral hazard by giving information update on a potential company share at all times that will enhance the efficiency of human, social and intellectual effectiveness (Venkataraman, 2019). Similarly communication effectiveness to investors (Parhankangas and Renko, 2017), effective and visual signal (Mohmood et al., 2019). In addition, any signal not in the direction of entrepreneur considered disambiguate and generate several issues from different entrepreneur point of view (Kuppuswamy and Bayus, 2017) cues for instance in the angle of endorsement and the investment decision by investors which has been found significant influential at the take-off stage which must considered important as partners also defined by (Wang, Mahmood, Sismeiro, \& Vulkan, 2019). Zhang et al., (20I5) Leading Equity Crowdfunding platforms such as CircleUp that encourage co-investment between the investor and crowd funder. On the other hand, some authors argue that the number of investors will eventually dominate the entire platform and deteriorate the democratising the channel. However, several studies emerged, besides no single researcher indicates how investor mainly interacted on digital platforms of crowdfunding.

The assessment of equity crowdfunding platform can be attributed undoubtedly an idea of new start-up business financing as no single financial institution will issues a credit without having any financial records, the longlasting repercussion for funding of any early start-up ventures funded is supervision. Such indicates an entrepreneur campaign and type of investment invented or innovated (Chan, \& Parhankangas, 20I7). It is, therefore, equity crowdfunding related to the information asymmetry, lack of transparent activities on the platform and the central information will only key to the entrepreneur and generate imbalance funding perpetuation based on 
conventional funding. Hemer et al. (20II) Crowdfunding mentioned as fundamental to research based on financial need platform. Hemer et al. (20I I) provide a general overview of the crowdfunding market in Germany. Their work contains basic principles, which can also be relevant to equity-based crowdfunding. At the same time, a few patterns can be identified that correlate with equity-based crowdfunding (for instance functions, like the thresholdpledge system). Furthermore, crowd investing uses a different approach compared to crowdfunding regarding the financing method. This implies different motivations of the money provider (we are already speaking of investors here), increasing possibilities for start-ups in terms of the amount of acquirable capital.

\section{Debt aspect of crowdfunding and financial intermediaries}

Debt Crowdfunding is a broader phenomenon which create a special benefit and shared by both the entrepreneur and crowd and is also known as peer-to-peer lending. It is a bigger part of the more massive revolution in "FinTech" (the combination of software and the internet that has been disintermediating the traditional finance industry). Whereas banks typically serve as intermediaries, taking deposits from savers and issuing loans to borrowers, but peer-to-peer lending platforms connect those with money directly to those who need it, and also allow savers to earn more and borrowers to pay less by cutting out the middleman (Mahomed, \& Ramadili, 2016). Therefore, these peer-to-peer lending sites is increasingly growing and do need to have Shariah framework to address the Muslims entrepreneur needs and to benefit from the crowds platform as Shariah compliant.

Proposed Equity-based and debt based crowdfunding through Musharakah, Mudarabah (Equity based) and Murabaha (Debt-based)

Our Proposed model is Crowdfunding Murabaha Debt Model (CMDM), Crowdfunding Musharakah Equity Model (CMEM) and Crowdfunding Mudarabah Equity Model (CMDREM) these models involve of two different parties, which consists of a crowdfunding platform and Islamic mode of finance. Thus, was considered to develop a strong model to fit the features and standardized Shariah complaints. Crowdfunding Murabaha Debt Model (CMDM) plan to develop and focus on initiating business and process of funding the business. For instance, to build a company and equip the company and expect the company to pay you within stipulated period agreed after the 
starting-up of the business. Therefore, the crowd funders are expecting their money back after sometimes with their mark-up as agreed upon the payment. The payment may categories into full or instalment payment depends on the agreement initially designed by platform. Furthermore, if the company delay or defaulted that can be treated based on Murabaha model the same Musharakah and Murabaha models. In addition, the entrepreneur sell the project idea for funding the innovated idea. The below descriptions are the proposed models designed for Shariah compliant crowdfunding investment.

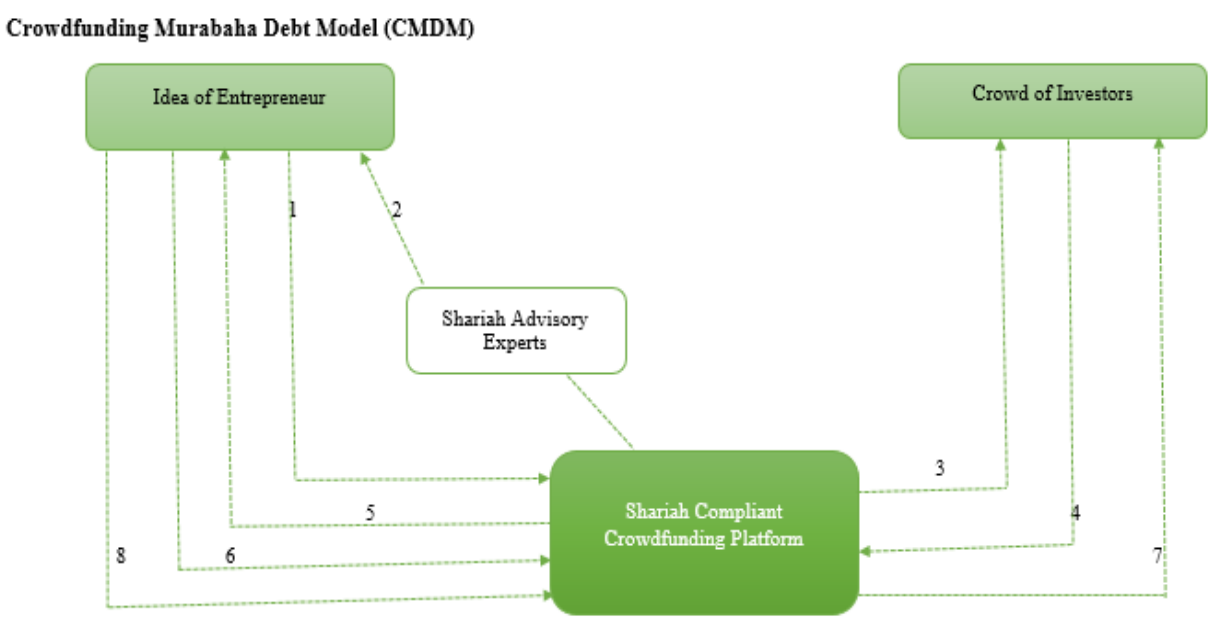

Source: Designed by authors

\section{Figure: I}

I. The idea of an entrepreneur to access fund to build a company or to purchase useful type of machinery that would generate income for business purposes

2. Investigate the idea by the Shariah expert and ensure the product is Shariah compliant or halal product before advertising crowd to fund the business

3. Products Advertisement

4. Investors subscribe and fund from the platform for the Shariah product

5. Raising capital to fund the project

6. Payback after some period stipulated plus cost-plus for the investors

7. Full payment or Instalment depends on agreement reached between entrepreneur and crowdfunding platform 
8. Pay the platform as agreed, in this scenario; the company has an option on-demand payment early on services to be rendered or after completing the company demand for payment.

Crowdfunding Musharakah Equity Model (CMEM)

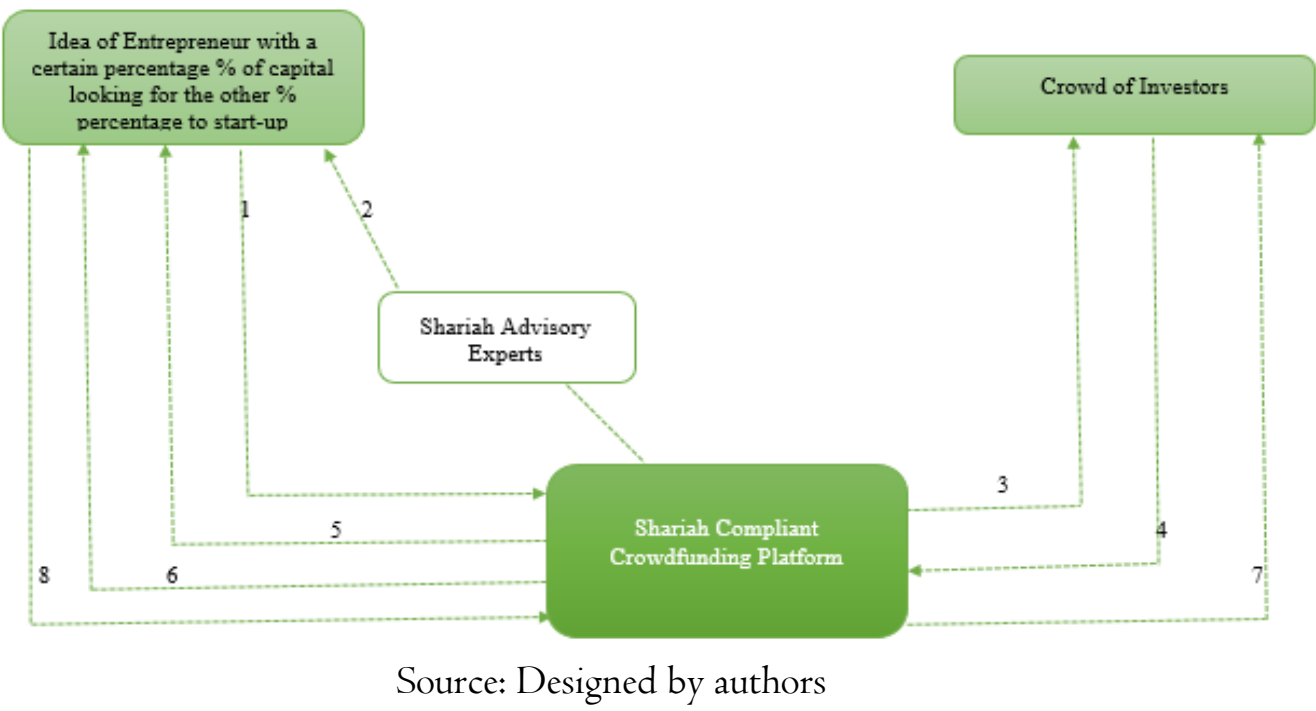

Figure: 2

I. Presenting the Idea as an entrepreneur to the crowdfunding platform for funding the investment idea

2. The Shariah expert will evaluate the project or investment to ensure the investment is Shariah-compliant

3. Advertise the investment Idea

4. Subscribe by the crowd as share depends on the number of amount an individual contributed

5. Supporting in raising capital from the crowd and fund the project

6. Constitute a monitoring committee to monitor the activities of the investment and report back to the investor to avoid a moral hazard or any information asymmetry that may cause uncertainty to the crowd

7. Distribution of dividends to the respective shareholder based on agreed percentage while loss shares based on capital contributed

8. Pay the platform company, in this scenario; the platform has the option to demand payment early on services to be rendered or after completing the company demand for payment. 
NB: Furthermore, maturity and termination of contract of any parties, depends on individual decision, if he/she wishes, only allow the management to know before terminating for making the processes easy to access the liquidity.

\section{Crowdfunding Mudarabah Equity Model (CMDREM)}

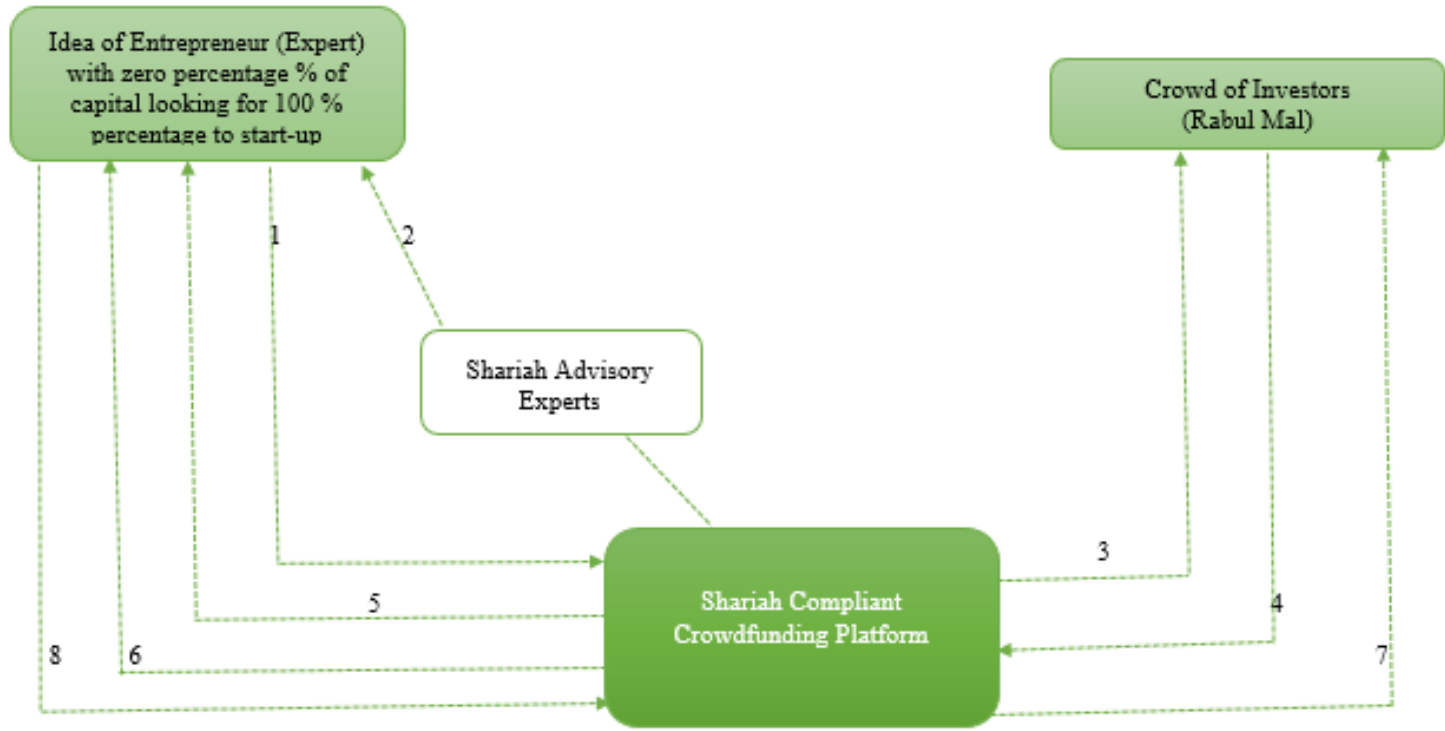

Source: Designed by authors

Figure: 3

I. Presenting the Idea as an entrepreneur (Expert in the field) to the crowdfunding platform to fund the investment idea

2. The Shariah experts will evaluate the project or investment to ensure the investment is Shariah-compliant

3. The platform will engage in advertising the Investment idea for funding

4. Subscribe from the crowd investors (Rabul Mal) who are willingly want to invest in the advertised projects or investment

5. Delivering the raised capital from the crowd (Rabul Mal) to the project funding

6. Constitute a monitoring committee to monitor the activities of the investment and report back to investor at the take-off stage to avoid a moral hazard or information asymmetry that may cause uncertainty to the crowd

7. Distribution of profit to the respective capital owner (Rabul Mal) should be pre-agreed upon based on percentage, and loss shall only be shoulder and pushed to the capital owner if it is not a negligent from the Expert (Mudarib). 
8. Pay the platform company, in this scenario; the platform has the option to demand payment early on services to be rendered or after completing, the company demand for payment.

NB. No guarantee: means the Mudarib should not guarantee on the rate of return or guarantee of investment safety by the manager of the venture. However, the capital owner or (Rabul Mal) can willingly agree after some particular period, the Expert Mudarib can own the investment.

\section{Related Studies On Crowdfunding Awareness And Trust Model}

Hamari, Sjöklint, \& Ukkonen, (2016) investigates the people awareness and how the model works through online platform. The study indicated the level of awareness towards crowdfunding and how the platform works online. Using demographic analysis and relationship between the types of crowdfunding systems. Findings revealed that there was a relationship between awareness and crowdfunding in the developed country. However, the study also found that there is less concern towards the crowdfunding in the developing country, due to penetration of fraud cases of cybersecurity and lack of uncertainty of the system.

Burtch, \& Chan, (2018) examined the behavioural perception towards the crowdfunding platform, which considered to be online based platform sources of financing around the globe. The result shows that there is an element of trust issue between the platform and investors, whereby the system is effectively working, and the government is issuing regulation time to time for festering the growth and fit the content of the field. Similarly, Thaker (2018) investigated this issue in the field of crowdfunding and identified that the trust led to contribute towards the equity and debt-based crowdfunding. Therefore, it is clearly indicates that crowdfunding is still in the early stage of infancy in Nigeria, especially in Northern Nigeria. Where awareness is seem to be relatively low as scenario resample the Philippines as the level of awareness is below 46 per cent. Vergara (20I5) indicates 80 per cent of the respondents were aware of the crowdfunding platform and recognize the activity of the platform despite its local founders based, but only 58 per cent can recall the campaign of crowdfunding, which indicates the low awareness penetration. Liang, Wu, \& Huang, (2019) examined the role of trust management on the performance of the fundraising platform. The study explored the developed elaboration and likelihood model which test 829 crowdfunding project were 
access to test hypothesis. The findings indicate trust management promotes the performance of fundraising via creditworthiness of entrepreneur and peripheral interaction sponsor, which indicates significantly higher and considered effective compared to the central route. Thus, result aligns in consistence with the assumption, which derived from different characters of crowdfunding and further indicates dynamic interaction is better than statics. However, history success experienced enhanced trust establishment. Furthermore, the entrepreneur's success crowding moderated the effect of entrepreneur and funding performance positively.

$\mathrm{H}_{\mathrm{I}} \quad$ There is a positive and significant relationship between Awareness and Behaviour of the Shariah Compliant Crowdfunding Model.

$\mathrm{H} 2$ There is a positive and significant relationship between the Trust and Behaviour of the Shariah Compliant Crowdfunding Model.

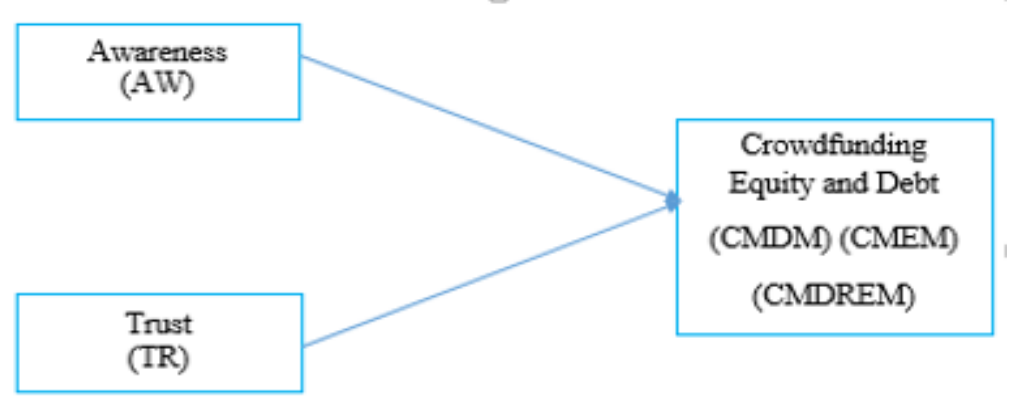

Figure 4: Measurement model based on Awareness and Trust relationship towards proposed debt and equity Crowdfunding

\section{METHODOLOGY}

\section{Measurement development}

The items used were adopted from the previous literature and validate instruments with some modification and amendment to match in line with the newly designed equity-based crowdfunding model, which consists of (Musharakah and Mudarabah) as Shariah-compliant, follow by debt-based crowdfunding, which only considered (Murabahah) model operation. The rated items are classified into measurement items using the Likert scale and five-point scale, ranging from I strongly disagree, and 5 strongly agree. The questions were drafted in English. However, a pilot test is conducted for accuracy and justification. On the other hand, the validation and reliability of the scale to 
ensure retest reliability. Therefore, the pilot data indicates satisfactory and reliable.

\section{Survey Procedure}

The research used Nigeria, specifically Northern Nigeria, for the growth of the region based on Shariah-compliant, and ensure debt and equity crowdfunding are in line with Shariah. Crowdfunding considered as a recent phenomenon that people interact within in order to raise capital for potential entrepreneur's business, despite its popularity in the world, However, Northern Nigeria are less aware of such activities and has less concern to enjoy the opportunity, where masses are suffering from funding skills and innovation depreciation by a conventional system that explore by interest-bearing. Therefore, it has been predicted by the World Bank that the crowdfunding industry will be expanded to reach 50 bn by 2025 . Furthermore, a suitable place like China has already reached out to $8.45 \mathrm{bn}$ (Thanker, Thanker and Pitchay, 2017). A favourable and friendly environment attracts a solid foundation for investment based on the proposed crowdfunding model of Shariah-compliant in Northern Nigeria.

The purposive sampling method was used for data collection from the general public in Northern Nigeria with the proposed model of crowdfunding developed based on Shariah complaint. The data collected from I8 years old and above in the states of Kano, Bauchi, Kaduna, Borno, Nasarawa, Adamawa and Sokoto. These states were selected due to the higher number of population and intellectuals are considered the strong hole of Northern Nigeria with a significant number of Muslim. The purposive method adopted as the participants were chosen to willingly provide information based on their knowledge and virtues of their understanding. The sampling involves the identification of an individual, which consists of demographical data and level of awareness and trust of the system of crowdfunding.

Sample size, the total number of 3000 questionnaires were distributed, and 2730 were returned. According to Hair et al., (2006) opined that sample size for structural equation Modeling (SEM) range from 200 to 400 to justify results accuracy and Kline (20II) supported the opinion of 200 above sample will consider adequate for modeling. The behaviour aspect of a crowd to three proposed model (CMDM), (CMEM) and (CMDREM) were tested using Confirmatory Factor Analysis (CFA) to examine the series relationship between the independent and dependent variables. The (CFA) was used to confirm and 
figure out the measurement model and path analysis. In my pilot test essentially used Explanatory Factor Analysis (EFA) which generally used to access newly combined constructs where the items were not considered by any researcher as mentioned by (Child, 1990). However, Confirmatory Factor Analysis (CFA) is for established constructs items already in place for adoption from the existing theory, which was drive from it. The study employed a self-administered questionnaire. The questionnaire was based on Theory Planned Behaviour (TPB). Some constructs items were adopted from literature, and modification was made to be in line with the aim of the study. Each of the two independent variables consists of ( 7 items) and dependent variable carries ( 7 items). The data were analysed using Amos 23 version and SPSS statistics 23 version respectively. The model measurement was estimated before the structural model. A confirmation Factor Analysis was used to test validity and reliability checks for the proposed model.

\section{RESULTS AND DISCUSSION}

The table below indicates the number of respondents who participated in the research in general. Most of the respondents were at age group 30-40 with 42 per cent, 4I-60 at 36 per cent.

Table I

\begin{tabular}{|c|c|c|c|}
\hline Demo V & No. of Respondents & & Total (\%) \\
\hline \multicolumn{4}{|l|}{$\overline{\text { Age }}$} \\
\hline $18-29$ & 464 & I7 & \\
\hline $30-40$ & II 47 & 42 & \\
\hline $4 \mathrm{I}-60$ & 983 & 36 & \\
\hline 6I-above & 136 & & 5 \\
\hline \multicolumn{4}{|l|}{ Gender } \\
\hline Male & I856 & 68 & \\
\hline Female & 874 & 32 & \\
\hline \multicolumn{4}{|l|}{ Educational level } \\
\hline Secondary School & 300 & & II \\
\hline Bachelor & $\mathrm{I} 638$ & 60 & \\
\hline Postgraduate (Mast & D) $\quad 792$ & & 29 \\
\hline
\end{tabular}


Tijjani Muhammad ${ }^{1}$ and Assoc. Prof. Dr. Besar bin Ngah ${ }^{2}$

\section{Occupational}

Public

874

32

Private

Self-employed

1502

273

Retired

137

819

55

I0

Students

5

30

Monthly income

Less than N30, 000

573

2I

NIO, 000-50,000

819

30

5I,000-NI00, 000

$4 \mathrm{IO}$

15

NIOI, 000-N200, 000

546

20

N20I, 000-N500, 000

273

More than N50, 000

109

I0

4

It is also indicated that majority of the respondents were Male with massive per cent of 68 per cent, and Female carries 32 per cent of the population. However, the marital status indicates 55 per cent and single handle only 45 per cent. In educational level, the majority of the respondents were educated whereby 60 per cent of the respondents have Bachelor's degree and 29 per cent postgraduate have master and $\mathrm{PhD}$, the remain II per cent were holding secondary school certificate. Most of the respondents were working in the public sector, with 55 per cent followed by 32 per cent working in the private sector, 30 per cent were students, IO per cent self-employed and retired are 5 per cent. Meanwhile, 30 per cent of the respondents were at the group earning NIO, $000-\mathrm{N} 50$, 000, and 2I per cent below N30, 000 per month.

\section{Table II}

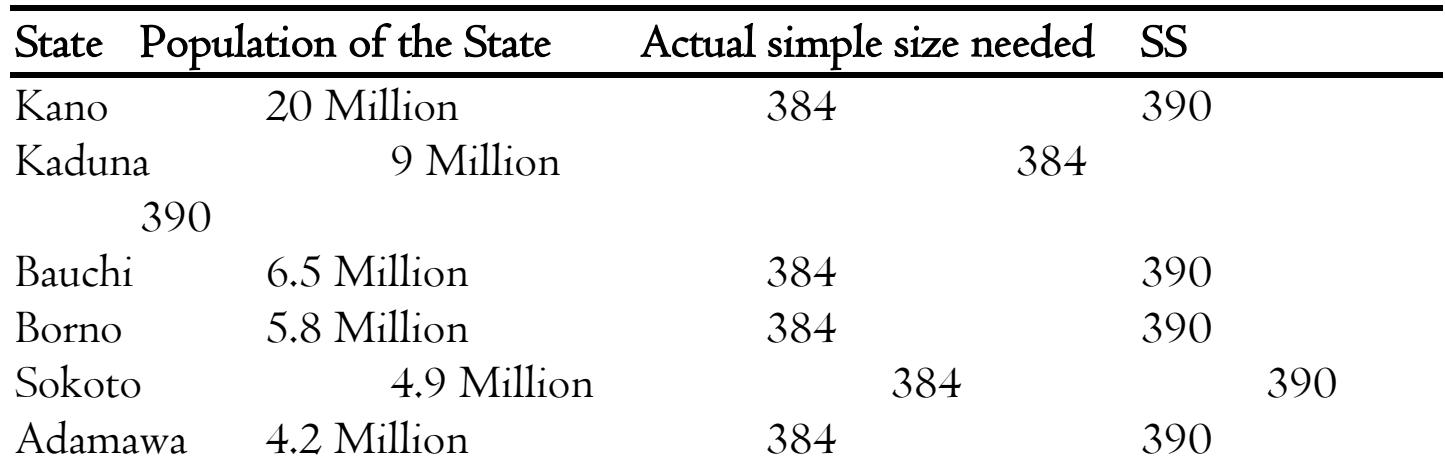


Nasarawa 2.5 Million

384

Total number samples size

*Confidence interval 5

${ }^{*} \mathrm{~S}$ S: Sample size

Table II identifies the population of each state based on their respective communities, despite Northern Nigeria has I9 states. However, the seven (7) states selected the most popular states with a significant number of intellectuals from three respective regions in Northern Nigeria, North-East, North-West and North-Central.

Figure 5 Model Measurement

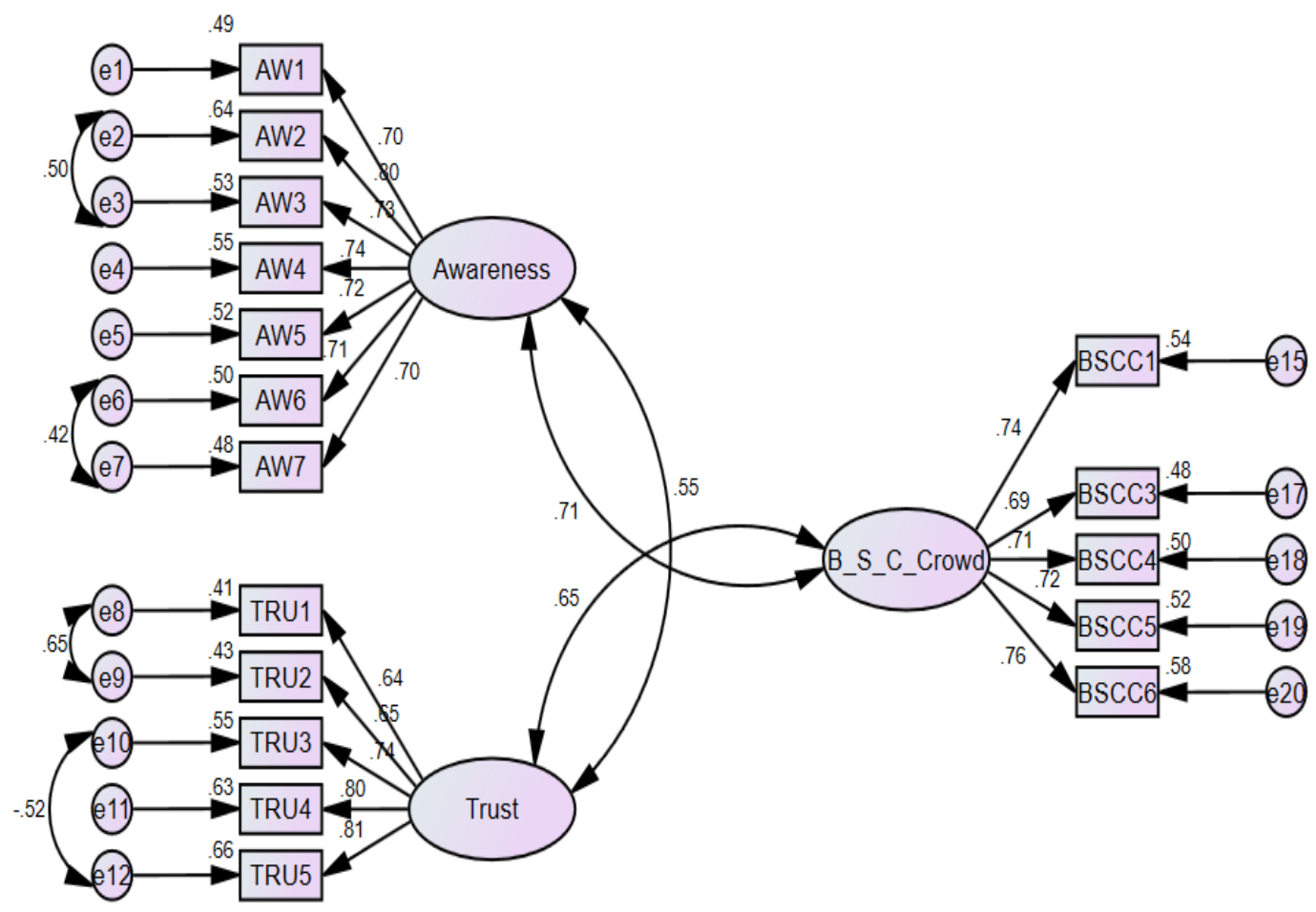




\section{Table III Measurement Model}

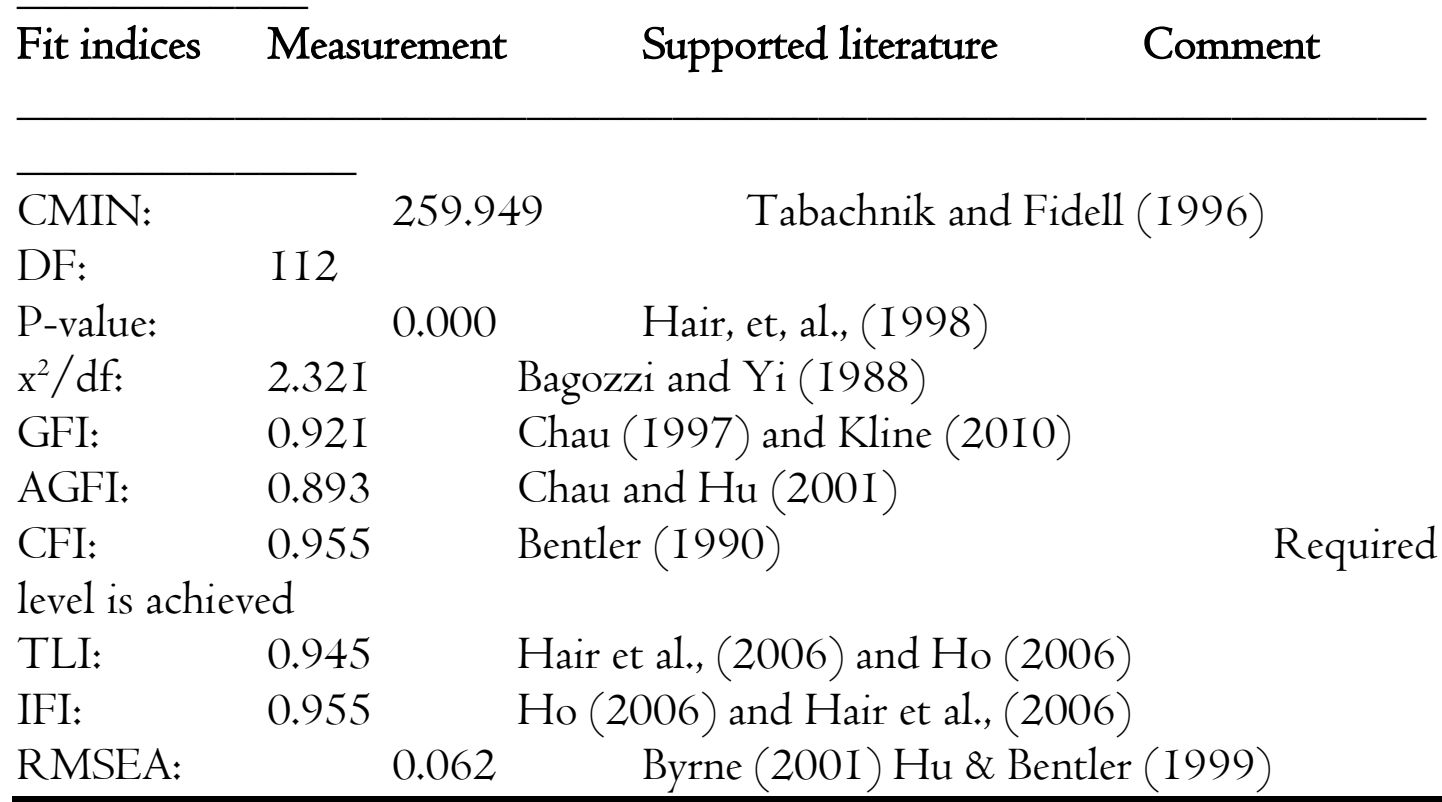

Table III shows the measurement model using Confirmatory Factor Analysis (CFA) with I7 items after the pilot test and deleted some correlated items. Thus, the model fit and indicates relevance by achieved the required level needed to fit the model. The overall result of model fit indices which initially shows the acceptability of model with $\mathrm{x}^{2} / \mathrm{df}=2.32 \mathrm{I}$ (Bagozzi and Yi 1988), GFI=0.92I (Hoyle 1995; Kline, 2010), AGFI=0.893 (Chau and Hu 200I), CFI $=0.955$ (Byrne, 20I3), TLI=0.945 (Hair et al., 2006; and Ho 2006), $\mathrm{IFI}=0.955$ (Ho, 2006; and Hair et al., 2006) and RMSEA $=0.062$ (Schumacker and Lomax, 20I0). However, all indices tested were all met the required standard, as shown above. However, the p-value is 0.000 , but in line with (Hair et al., 1998) and also be considered. Therefore, the model measurement shows the fit model through it indices as indicated and establish a relationship between the variables.

Table IV Construct reliability and convergent validity

\begin{tabular}{cccccc}
\hline $\begin{array}{c}\text { Constructs Items } \\
\text { Cronbach's } \alpha\end{array}$ & Mean & SD Factor loading CR & AVE \\
\hline
\end{tabular}

\begin{tabular}{llllllllll}
\hline Awareness & AWI & 3.85 & 0.864 & 0.697 & & 0.887 & 0.727 & 0.894
\end{tabular}




\begin{tabular}{|c|c|c|c|}
\hline & AW2 4.I3 & $\begin{array}{lll}0.836 & 0.797\end{array}$ & \\
\hline & AW3 4.09 & $0.874 \quad 0.730$ & \\
\hline & AW4 4.03 & $\begin{array}{lll}0.882 & 0.743\end{array}$ & \\
\hline & AW5 4.07 & $\begin{array}{lll}0.820 & 0.723\end{array}$ & \\
\hline & AW6 4.I7 & 0.7840 .706 & \\
\hline & AW7 4.I2 & 0.8090 .696 & \\
\hline Trust & TRUI4.23 & 0.8030 .639 & $\begin{array}{llll}0.85 I & 0.727 & 0.852\end{array}$ \\
\hline & TRU24.30 & $0.74 \mathrm{I} \quad 0.653$ & \\
\hline & TRU33.98 & 0.8300 .740 & \\
\hline & TRU43.84 & $\begin{array}{lll}0.890 & 0.795\end{array}$ & \\
\hline & TRU53.93 & $0.867 \quad 0.812$ & \\
\hline & TRU6 & 0.464 & \\
\hline & TRU7 & 0.398 & \\
\hline
\end{tabular}

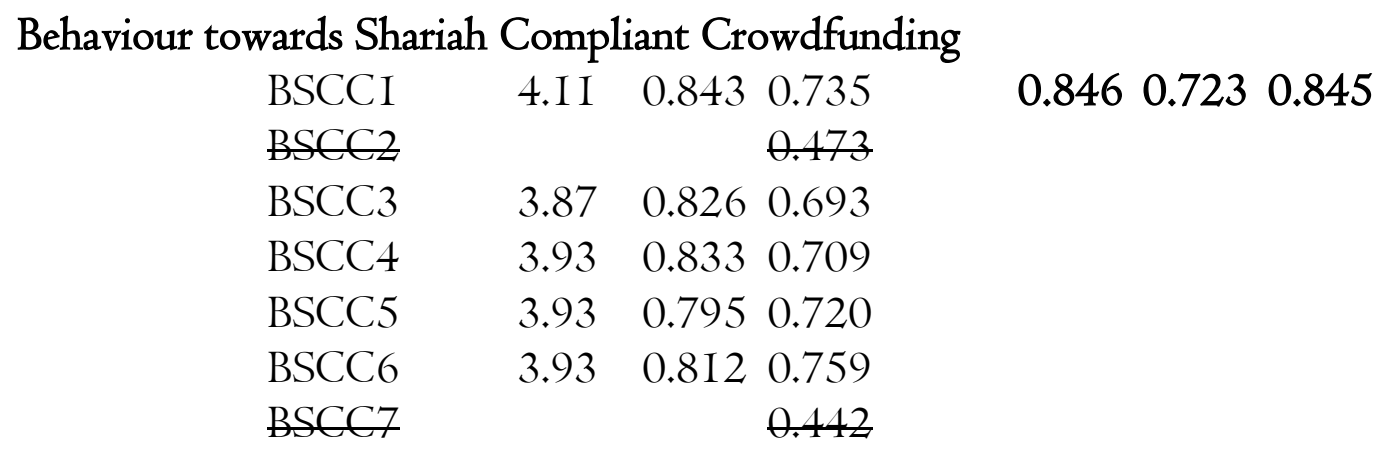

Table IV indicates the construct structure and how items have been modified based on modification indices to fit the model as needed if some of the loadings were below the required number stipulated as stated by (Fomell \& Larcker 198I). Therefore, the modification indices were used to straight the loading of latent variables as some were deleted and other covariant each other for better loading and model fitness in a CFA requirement. After accessing modification indices, two items of trust (TRU6, TRU7, BSCC2 and BSCC7 were deleted due to high modification indices ranging between 32.32I to 50.345) that indicates a high error. Thus, AW2, AW3, AW6, AW7, of Awareness, TRUI, TRU2, TRU3 and TRU5. With this amendment, the model fit the indices and indicates high and better model fit. The composite 
Modeling Debt And Equity Crowdfunding Based On Murabahah, Musharakah And Mudarabah: Trust And Awareness

Tijjani Muhammad ${ }^{1}$ and Assoc. Prof. Dr. Besar bin Ngah $^{2}$

reliability (CR), the average variance extracted (AVE) and Cronbach's alpha was used for consistency as stated by indicating good reliability (Fornell and Larcker, I98I). The recommended value for CR should be at least 0.6 as stated by (Hair et al., 20I0), AVE should be above 0.5 as recommended by (Fornell \& Larcker, I98I) and Cronbach's alpha should be greater than 0.7 (Hair et al., I998).

Table V Inter-construct correlation

\begin{tabular}{llll}
\hline Variables & AW & TRU & BSCC \\
\hline AW & I & & \\
TRU & 0.554 & I & I \\
BSCC & $0.7 \mathrm{II}$ & 0.646 & \\
\hline
\end{tabular}

The structural model measured to assess the relationship between the proposed variables. The results indicated that AW has a positive relationship with BSCC towards (CMDM), (CMEM) and (CMDREM) with 0.7II, and TRU is positively correlated with BSCC toward the three proposed model.

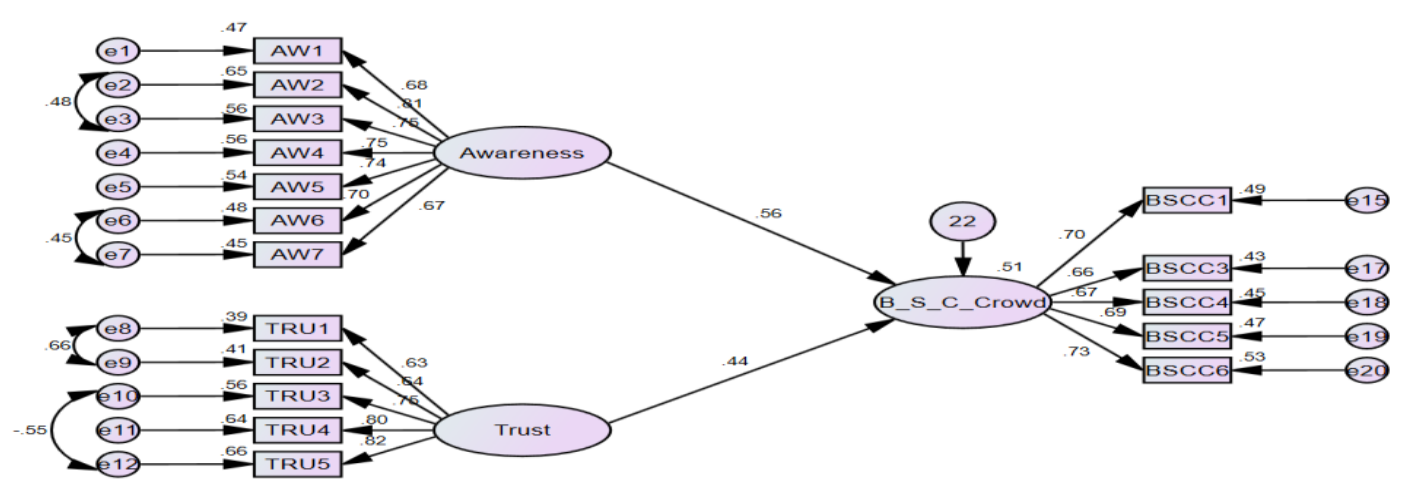

Figure: 6 Hypotheses Measurement

Table VI Hypotheses

\begin{tabular}{ccccc}
\hline Hypotheses Estimate & SE & CR & P & Hypotheses result \\
\hline AW - $>\quad$ BSCC 0.559 & & 0.065 & 8.264 & 0.000 \\
Supported (HI) & & & &
\end{tabular}




\section{$\begin{array}{lllll}\text { TRU _> BSCC } & 0.442 & 0.70 & 7.053 & 0.000\end{array}$ \\ Supported (H2)}

Similarly, AW and TRU play a significant role in addressing and influencing needs of crowdfunders to use any of the three models. Meanwhile, AW and TRU were positively associated with improving the usability of the three models to enhance the value and acceptabilities from the crowdfunders. Moreover, Table VI, indicates the relationship between AW->BSCC is statistically significant, when Awareness goes-up by I standard deviation, BSCC goes up by 0.559 standard deviation where the standardize coefficient shows, (Estimate $0.559, \mathrm{CR}=8.264<0.00 \mathrm{I}$ ) this offers the support and the existence of the relationship between AW and BSCC. This could be explained that the needs of awareness towards the behaviour of Shariah-compliant crowdfunding which consist of both parties entrepreneur and investors. Thus, needed due to unskilled of the computer-based individual in the side of investor or entrepreneur is quite relaxed and reluctant to be involved in crowdfunding.

Similarly, the result shows the absolute relation between the TRU and BSCC with statistically significant (Estimate $=0.442, C R=7.053 \mathrm{P}<0.00 \mathrm{I}$ ) that indicates the supports the hypothesis, such means that if TRU goes up by I standard deviation BSCC goes-up by 0.494 standard deviations. As such, TRU has agreed in developing that the investor may have trust towards the entrepreneur for the successful operation of the crowdfunding activities.

\section{Study Discussion Discussion}

The objectives of the proposed research have been achieved and sustained the model prediction for financing Shariah-compliant crowdfunding to address the need for funding of an innovated or invented idea in Northern Nigeria. The models suggested that Crowdfunding Murabaha debt model (CMDM), Crowdfunding Mudarabah Equity Model (CMEM) and Crowdfunding Musharakah model (CMDREM) were used in subsequence to test the relationship from awareness and trust. Generally, the result indicates the positive relationship between the awareness and behaviour of Shariah-compliant crowdfunding as the same as trust.

Therefore, Islamic finance promotes an ethical and standard financing system and ensures the equal right and distribution of wealth and investment are 
highly protected among all parties. The awareness and trust become significant as all information related to the entrepreneur, and its innovation must be disclosed to investors and connect both parties through giving out information and updates of project progress. However, the mechanism of debt-based crowdfunding, instead, will be operated based Murabaha which is classified as a positive step forward to attached Shariah principles for avoiding any mischief and unethical financial transaction for Muslim and the general public to benefit. The same with equity-based which will be operating based on partnership arrangement towards Murabaha and Musharakah system of operation.

Based on the results, the attributes and behavioural attitude towards using crowdfunding are based on awareness and trust of the Shariah complaints system, which significantly depends on what Shariah stipulated, and subsequent the trust on decision enquired. This study strongly believes the power to attract the vast population to participate in crowdfunding lies upon Shariah-compliant activities which applying AW and TRU will also ginger the activities and performances of the system particularly that of debt-equity based operations. Thus, using the three models developed would be used through an online platform and also help crowdfunders to initiate a positive perception of models in Nigeria and Nigerian Muslims in general. The finding is consistent with Thaker, Thaker, and Pitchay (2017).

\section{E. CONCLUSION}

\section{Conclusion}

The study examines the concept of crowdfunding and its works and benefits to the Muslim society in Northern Nigeria, with the rapidity number of crowdfunding platforms. The study evaluated the current platform for crowdfunding and added some features to meet the requirement of Shariahcompliant to maintain SEC framework to suit the Muslim believe and acceptability, which considered as an alternative for Non-Muslim and necessary for Muslim to avoid doubt and uncertainty in conventional operation of crowdfunding.

From the Managerial aspect, the findings raised an investment platform based on Shariah-compliant using (CMDM), (CMEM) and (CMDREM) which will initially bring benefit for the both parties, investors and entrepreneur. Considering the potential usage of three proposed models. Thus, also essential to ensure people are enlightened and engage with it, to achieve the objectives. As such, the attention must be given to awareness to draw more enlighten to the 
system usefulness. Another managerial implication, the study assist the institution in setting the project flexible based on priorities, depending cost, quality and Flexibility of the project.

\section{Limitation}

The study contributes towards the development of the (CMDM) (CMEM) and (CMDREM) and shows the factors that influence the behaviour Shariah Compliant crowdfunding in Northern Nigeria through AW and TRU given to Shariah framework. Some of the limitations generated, the restricted area and the sample size used are considered limited. However, there is a need to be specific in avoiding generalize the results and conclusion of the study. Besides, the use of two factors to determine the acceptability of awareness and trust potentially towards the proposed model. The future research can be seen in bringing the new factors and mediation and moderation variables to be added to the research model for more robust and sustainable operation. 


\section{REFERENCE}

Ajai, O. (2012). Law, water and sustainable development: framework of Nigerian law. Law Env't \& Dev. J., 8, 89.

Akwe, J. A., \& Garba, S. B. (2019). Effects of Internal and External Factors on

Stock Returns of Large Size Firms in Nigeria. Global Journal of Accounting, 5(I), 44-56.

Alam, N., \& Rajjaque, M. S. (2016). Shariah-compliant equities: Empirical evaluation of performance in the European market during credit crunch.

In Islamic Finance (pp. I22-I40). Palgrave Macmillan, Cham.

Bagozzi, R. P., \& Yi, Y. (1988). On the evaluation of structural equation models. Journal of the academy of marketing science, I6(I), 74-94.

Bentler, P. M. (1990). Comparative fit indexes in structural models.Psychological bulletin, I072), 238.

Brem, A., \& Wassong, N. (20I4). Wer investiert warum. Eine Analyse von Investmententscheidungen bei Crowd funding - Projekten. ZfKEZeitschrift für KMU und Entrepreneurship, 62, 3I-55.

Brulle, R. J. (20I4). Institutionalizing delay: foundation funding and the creation of US climate change counter-movement organizations. Climatic change, I22(4), 681-694.

Burtch, G., \& Chan, J. (2018). Investigating the relationship between medical crowdfunding and personal bankruptcy in the United States: Evidence of a digital divide. MIS Quarterly (Forthcoming).

Byrne, B. M. (20I0). Structural equation modeling with AMOS: basic concepts, applications, and programming (multivariate applications series). New York: Taylor \& Francis Group, 396, 7384.

Chan, C. R., \& Parhankangas, A. (2017). Crowdfunding innovative ideas: How incremental and radical innovativeness influence funding outcomes. Entrepreneurship Theory and Practice, 4I(2), 237-263.

Chau, P. Y. (1997). Reexamining a model for evaluating information center success using a structural equation modeling approach. Decision Sciences, 28(2), 309-334.

Chau, P. Y., \& Hu, P. J. H. (200I). Information technology acceptance by individual professionals: A model comparison approach. Decision sciences, 32(4), 699-719.

Child, D. (1990). The essentials of factor analysis. Cassell Educational. 
Davis, M., \& Cartwright, L. (2019). Financing for Society: Assessing the Suitability of Crowdfunding for the Public Sector. https://books.google.com.ng/books?hl=en\&lr=\&id $={ }_{w} Y i U D w A A Q B A$ J\&oi

Freedman, D. M., \& Nutting, M. R. (20I5). The foundations of online crowdfunding, in equity crowdfunding for investors: A guide to risks, returns, regulations, funding portals, due diligence, and deal terms. Hoboken. NJ: Wiley, IO, 978 I I I8864876.

Grèzes, V., Emery, L., Schegg, R., \& Perruchoud, A. (2015). Crowdfunded tourism activities: Study on the direct impact of Swiss crowdfunding platforms on the tourism industry. In Conference: Travel \& Tourism Research Association (pp. I-I0).

Hagedorn, A., \& Pinkwart, A. (2016). The financing process of equity-based crowdfunding: An empirical analysis. In Crowdfunding in Europe (pp. 7I-85). Springer, Cham.

Hagedorna, A., \& Pinkwartb, A. (2013). Crowdinvesting as a Financing Instrument for Startups in Germany. A Critical Platform Analysis, I7.

Hair Jr JF, Black WC, Babin BJ, Anderson R, Tathum R. (2006). Multivariate data analysis. 6th ed. Upper Saddle River: Prentice Hall; 2006.

Hair, J. F., Anderson, R. E., Tatham, R. L., \& Black, W. C. (I999). Análisis multivariante (Vol. 49I). Madrid: Prentice Hall.

Hamari, J., Sjöklint, M., \& Ukkonen, A. (2016). The sharing economy: Why people participate in collaborative consumption. Journal of the association for information science and technology, 679), 20472059.

Ho, R. (2006). Handbook of univariate and multivariate data analysis and interpretation with SPSS. CRC press.

Hornuf, L., \& Schmitt, M. (2016). Success and failure in equity crowdfunding. CESifo DICE Report, I4(2), I6-22.

Kline, R. B. (2010). Promise and pitfalls of structural equation modeling in gifted research. In B. Thompson \& R. F. Subotnik (Eds.), Methodologies for conducting research on giftedness (p. I47169). American Psychological Association. https://doi.org/I0.I037/I2079-007

Kline, R. B. (20I I). Convergence of structural equation modeling and multilevel modeling (pp. 562-589). na. 
Kuppuswamy, V., \& Bayus, B. L. (2017). Does my contribution to your crowdfunding project matter?. Journal of Business Venturing, 32(I), 72-89.

Liang, T. P., Wu, S. P. J., \& Huang, C. C. (2019). Why funders invest in crowdfunding projects: Role of trust from the dual-process perspective. Information \& Management, 56(I), 70-84.

Lipusch, N., Dellermann, D., Bretschneider, U., Ebel, P., \& Leimeister, J. M. (2020). Designing for Crowdfunding Co-creation. Business \& Information Systems Engineering, I-I7.

Mahomed, Ziyaad and Ramadili Mohd, Shamsher Mohamad. (2016). Managing risk in the Islamic finance sector. CIAWM Bulletin, 3, pp. I - I6.

Moritz, A., \& Block, J. H. (20I4). Crowdfunding und Crowdinvesting: Stateof- the-Art der wissenschaftlichen Literatur (Crowdfunding and Crowdinvesting: A Review of the Literature). Zeitschrift für KMU und Entrepreneurship, 62(I), 57-89.

Rahman, M. P., Duasa, J., \& Kamil, N. (2016). Factors Contributing To The Success of Crowdfunding: The Malaysian Case. In Asia-Pacific Conference on Economics \& Finance (APEF) (Vol. 27).

Sapovadia, V. (20I7). Jaiz: The Birth of Non-Interest Banking in Nigeria. Developing Africa's Financial Services: The Importance of HighImpact Entrepreneurship, 199.

Stanko, M. A., \& Henard, D. H. (2017). Toward a better understanding of crowdfunding, openness and the consequences for innovation. Research Policy, 46(4), 784-798.

Tabachnik, B. G., \& Fidell, L. S. (1996). Using multivariant statistics New.

Mohd Thas Thaker, M.A.B. (2018), "A qualitative inquiry into cash waqf model as a source of financing for micro enterprises", ISRA International Journal of Islamic Finance, IO (I), pp. I9-35. https://doi.org/I0.II08/IJIF-07-2017-00I3

Torabi, O., \& Mirakhor, A. (2020). Crowdfunding with Enhanced Reputation Monitoring Mechanism (Fame) (Vol. 3). Walter de Gruyter GmbH \& Co KG.

Venkataraman, S. (2019). The distinctive domain of entrepreneurship research. In Seminal ideas for the next twenty-five years of advances. Emerald Publishing Limited. 
Wang, W., Mahmood, A., Sismeiro, C., \& Vulkan, N. (2019). The evolution of equity crowdfunding: Insights from co-investments of angels and the crowd. Research Policy, 48(8), 103727.

Wennberg, K., Pathak, S., \& Autio, E. (2013). How culture moulds the effects of self-efficacy and fear of failure on entrepreneurship. Entrepreneurship \& Regional Development, 25(9-10), 756-780.

Appendix

TABLE VII Constructs items and its full description

Constructs Items Description

Awareness

AWI I have a foundation knowledge of crowdfunding.

AW2 I am aware of the existence of Shariah-compliant crowdfunding

AW3 I am aware of the principles of the shariah-compliant framework

AW4 I am aware of how Murabahah and debt financing works

AW5 I am aware of how Musharakah and equity financing works

AW6 I am aware of how Murabahah and equity financing works

AW7 It know that Shariah-compliant can fit the debt and equity model

\section{Trust}

TRUI I am very sure and relax with the truthful system of Shariah Crowdfunding.

TRU2 I strictly adhered the truthful obligations on transaction as a Muslim, which are in line with Shariah-compliant

TRU3 I always participate in Shariah-compliant products and services as I believe a truthful means of transaction

TRU4 I have less fair in participating in Shariah-compliant crowdfunding TRU5 I am planning to participate in Shariah-compliant debt and equity crowdfunding best on the trust of the Shariah framework

TRU6 I want to participate in Shariah-compliant crowdfunding as people are participating

TRU7 I am planning to use Shariah complaint Crowdfunding because is rendered best services and higher return

\section{Behaviour towards Shariah Compliant Crowdfunding}


Modeling Debt And Equity Crowdfunding Based On Murabahah, Musharakah And

Mudarabah: Trust And Awareness

Tijjani Muhammad ${ }^{1}$ and Assoc. Prof. Dr. Besar bin Ngah ${ }^{2}$

BSCC IShariah Compliant is useful in enhancing Shariah entrepreneurship and business arena and balance risk and investment loss towards crowdfunding

BSCC2 Shariah Compliant needed only in balancing risk and equity distribution towards crowdfunding

BSCC3 Security Exchange Commission (SEC) should be considered people behavior towards Shariah-compliant products to balance in innovation or Fintech application towards issuing guideline policy at all time

BSCC4 I prefer Shariah crowdfunding than conventional once

BSCC5 I prefer to invest and participate in debt and equity crowdfunding based on Shariah-compliant

BSCC6 I can agree to partner with fully Shariah-compliant due to the free system of interest rate, gambling and speculation

BSCC7 I do not care using any of the two crowdfunding, Islamic or Conventional crowdfunding 